He'd listen politely but seldom change his mind. "In my judgment," he'd begin. "But," I would regularly interrupt, "good judgment has to be based on evidence." Just as regularly he would spring the trap: "But $I$ must have good judgment. Didn't I pick you to come here?"' There was no answer, at least none that would strengthen my case.

In his Sonnet \#12 Shakespeare wrote that " 'gainst Time's scythe" no man can make defense except in his offspring. Here Alph blunted Time's blade. His daughter, son-inlaw, three granddaughters, and two great grandchildren live on with Christine. But so do generations of Princeton undergraduates and graduate students, as do students from the fifteen universities at which he taught after his so-called retirement. Many of these people are now journalists, judges, lawyers, and professors. They are fulfilling Alph's usual parting command: "Carry on." If they are not doing so in the Brandeis way, certainly they are in the Mason way. And the world is much the better for it.

Unlike Thomas Wolfe, we shall not have to spend time "remembering speechlessly" or seeking that "lost, and by the wind grieved, ghost"; we need not cry out "come back again." For whenever constitutional scholarship is done, Alph's ghost-Alph's spirit-will be with us, rustling judicial papers, recalling the framers' wisdom, tweaking Felix Frankfurter, and reminding us of the responsibilities and the joys of "free government" and free men's-and free women's-lives.

Walter F. Murphy

Princeton University

\section{Llewellyn E. Pfankuchen}

A devoted and learned member of our profession over many years, Professor Emeritus Llewellyn E. Pfankuchen died in his sleep on August 15,1989 , at age 85 . He had been continuously a member of the American Political Science Association since 1927, and thus, at the time of his death, for a longer period than all but five living members. For forty of those years (1932-72) Llewellyn was a respected member of the fac- ulty at the University of WisconsinMadison.

Llewellyn was born in Oshkosh, Wis., on May 7, 1904, grew up in Minneapolis and graduated magna cum laude from the University of Minnesota (1924). After a stint of public school teaching in Highmore, S.D., he began his graduate education at the University of Illinois, attaining an M.A. in 1926, and completed it at Harvard University with a Ph.D. in 1931. He gained additional teaching experience at the New Jersey Law School, interrupting his graduate work to do so. After completing his doctorate he began his professional career at Duke University but after only one year joined the faculty at Madison (1932). Here he rose from the rank of instructor to that of full professor and was designated chairman of the department in 1944, serving until 1948. He served in 1948 as President of The Midwest Conference of Political Scientists (now the Midwest Political Science Association).

During his long tenure at Wisconsin, Llewellyn taught, at one time or another, nearly every course in the curriculum but the center of his scholarly interest was international law. With a few interruptions he taught the courses in this subject offered by the department throughout his years of service. His Documentary Textbook in International Law (1940) was for years one of the standard works in this field. After World War II, he became deeply interested in the political aspects of international relations and together with a distinguished professor of geography (Richard Hartshorne) completely reorganized the basic courses in this field offered by the department. The new approach focused on the nation-state as a going concern, the relations between the internal and external politics of nations, and the development of institutions for mediating interstate conflicts, combining in each phase the unique insights of geography and political science.

During the New Deal era, Llewellyn served in one of the main sources of national agricultural policy, the Bureau of Agricultural Economics of the U.S. Department of Agriculture, and brought back to the campus his enthusiasm for rural America and its local governmental institutions. His most important public servic was his work during and after World War II in the State Department helping to prepare the groundwork for a new international institution and at the conference in San Francisco (1945) at which the Charter for the United Nations was prepared. His strong support for the U.N. continued throughout his active life. He served on annual state and local commissions providing grassroots support for and understanding of the U.N. and was director for several summers of a seminar in New York City for university students on the U.N. and its operations. The students who were privileged to participate regarded the U.N. experience as one of the high points of their education.

The three of us whose signatures appear below were not only longtime departmental colleagues of Llewellyn's but also, earlier, among his many students-one of us as a graduate student and the other two as undergraduates. Like most of his other students, including several who achieved distinguished careers at other universities or in public service, we admired Llewellyn's teaching and were encouraged by it to continue our study of political science. Then, when fortunate enough to be Llewellyn's colleagues, we came to appreciate his fairness, discriminating judgment, and agreeable disposition. Llewellyn's judiciousness was a model of professional behavior, and his warm friendship was cherished by all of us.

Besides his considerable involvement in University affairs, Llewellyn participated in various civic and community organizations. He loved choral singing and was an early and active member of the Philharmonic Chorus of Madison. He is survived by his wife, Gretchen, and two children, David and Heidi.

William H. Young

Leon D. Epstein

Clara Penniman

University of Wisconsin-Madison

\section{John Adams Wettergreen}

John Adams Wettergreen, 45, died suddenly of a heart attack after a 
racquetball game with his son, Joshua, a political science major at the University of Dallas. $\mathrm{He}$ is also survived by his daughter, Rachel, a student at UC-Davis, and his wife of 26 years, Carolyn R. (Cass) Wettergreen. He was a descendent as well as a namesake of the second president of the United States.

With the exception of a summer at the Graduate Institute of St. John's College, Santa Fe, John's entire 22year teaching career was at San Jose State University, where he taught political philosophy, American government, and American studies and was in the Honors program of the Humanities Department. In recent years, he had received a series of National Endowment for the Humanities awards, principally for conducting institutes on the Founding for area social science teachers. A recent Bradley fellow of the Heritage Foundation, he had won three successive merit awards for scholarship and service at San Jose State, the most recent coming posthumously. He was a full professor by the age of 30.

Those wishing to help John's children finish their educations may donate to a trust fund set up by his sister, Beth Morgan, and Dr. Larry Peterman, professor of political science, the University of California at Davis, and a dear friend. Checks may be made out to The John Wettergreen Educational Trust and sent to Dr. Peterman, 655 Portsmouth Avenue, Davis, CA 95616.

John's colleagues think that the following tribute paid him at his funeral by his friend and teacherfirst at Ohio State University and later at the Claremont Graduate School-Dr. Harry V. Jaffa, professor emeritus at Claremont, will serve as the best indication of the loss that John's death brings to political science and to the polity. For his family and friends, the loss is overwhelming and irreparable.

Fauneil J. Rinn

San Jose State University

\section{Funeral remarks by Harry V. Jaffa:}

It is the prayer, I think, of every mother and father, that their children should bury them. A teacher has an extended family, and lives in the hope of an immortality in this world from his students as well as from his own children. Johnny entered my life, and our family's, in 1962 when, I believe, he was younger than [his son] Josh is today. It is almost exactly a month ago that John spoke in my honor at my "retirement" banquet in Claremont. He said that we met in the weight room at the Ohio State Natatorium, and that I could do more pull-ups than he could. That, I want to announce, was a noble lie! I was never in John's class as an athlete, certainly not the athlete he was at the age of nineteen, when he had recently been a high school All-American swimmer and a national record holder. When I met him-which I recollect as having been in the pool-he had one of the most perfectly conditined and proportioned physiques I have ever seen. He could have served as a model for a statue of Praxiteles.

I met John in the fall of 1962made memorable by the Cuban Missile Crisis-when Wayne Thompson was taking my introductory course. Wayne and John had both been high school All-American swimmers, and both were at Ohio State on athletic scholarships. They were already close friends, and I was one of the things they decided to share. In any event, I soon became an advisor to both of them in the honors program, a very elite program in the Liberal Arts College at Ohio State. The "bright college years" that followed are golden years in my memory, as in my wife's. Wayne took his junior year in Germany, while John was earnestly studying Greek. Wayne and Susie, and John and Cassie, did their courting very much under our discreet but enthusiastic watchfulness. They were in and out of our Columbus home as much as my classroom and office.

The bonds of affection that were formed then could hardly have been greater had they been our own children.

I can hardly leave the Ohio years without remarking John's political activities in 1964. I had joined Ohioans for Goldwater in 1963, and soon thereafter became faculty advisor to the Young Republicans at Ohio State. John's hard-boiled Conservative Republicanism congealed into a mold that never changed-albeit his political sophistication never ceased to grow. John was one of the leaders in organizing the mock Republican National Convention in the spring of 1964. At that time the struggle between Barry Goldwater and Nelson Rockefeller for the Republican presidential nomination was still hanging in the balance, and was most intense. Ohio State was then the single largest campus in the nation, and mock conventions were watched with the most ardent interest by political partisans and by the press. I remember the night before the Convention opened, standing beside the bar in the Ohio Stater Inn with Gerald Ford (then the Republican leader in the House), who had come to Columbus to give the keynote address the next day. A well dressed but rather sleazy character sidled up to Ford, and attempted to ingratiate himself. He proved to be a Rockefeller representative and (as we later learned) he was loaded with cash. "That doesn't speak very well for Nelson Rockefeller," was Jerry's remark to me after that worthy departed. (I often wondered if-in later years-President Ford remembered that episode when he appointed Rockefeller to the VicePresidency.) Be that as it may, I learned later from John that the Rockefeller man had showered thousand dollar bills on prospective Rockefeller supporters on the Convention floor. But it was to no avail when matched against the skill and energy of the floor manager of the Goldwater campaign-John Wettergreen. Let us remember that, although the Republicans lost the presidential election in 1964, they have lost only one of the six presidential elections that have followed. John made his own contribution to that outcome.

As a scholar and teacher, John combined the most exacting classical learning and philosophical depth with the most realistic appreciation of practical politics. His study of Harrington-which must be published some day-combined textual exegesis with interpretation of the highest order. No sufficient understanding of the American founding-with its peculiar blend of both ancient and modern republicanism -is possible, 
that does not take into account John's contribution. His essay in the Western Political Quarterly, in the early 1970s, on "Snobbery as a Formal Value: Reflections on the End of Modernity," was pronounced at the time, by no less a personage than Joseph Cropsey, as the finest theoretical writing by any member of John's generation, a commendation richly deserved. In recent years his work has taken a turn that most observers would regard as eminently practical and political. Nevertheless, in 1984 he published an essay entitled "Elements of Ancient and Modern Harmony," which may possibly be not only the finest, but the most theoretical writing of his generation. It is the only attempt I know to understand the question of ancients and moderns in the light of ancient and modern music, by understanding the difference between singing and speaking, and by understanding the human soul, qua rational and qua irrational, in the light of the rationality and irrationality of the different harmonic modes. John points out that it was Aristodemus, the pupil of Aristotle (known as the Musician, as his master came to be known as the Philosopher), who resolved the question of harmonics in argument with the Pythagoreans, by the same appeal to sense perception (as opposed to mathematical abstractin) as that by which Aristotle resolved the question of Being. John's discussion of
Bach's Well Tempered Clavier in the light of his account of the problematic character of harmony, is a tour de force of the greatest brilliance. Although it will be some years, I fear, before I have assimilated it fully, I have no doubt that it will be the foundation of any serious understanding of the relationship between politics and music that is at the heart of classical political philosophy.

In recent years, John has written with ever increasing power on the matter of government regulation. He has given concrete definition to much of that "soft tyranny" that Tocqueville foresaw as the peculiar course of democracy. John has warned however that this tyranny may not be nearly so soft as Tocqueville imagined. Let us hope that his book in this regard, so nearly completed, will be published presently, and its lessons taken to heart. Here I would mention John's indictment of the public health bureaucracy in the AIDS controversy. John showedbeyond a reasonable doubt, I would say-that public health officials had put the perverse interests of sodomites ahead of the health of the public they were elected to serve. The attacks against John that this evoked were as unrestrained as any seen in my lifetime. But when John delivered his rebuttals, there were no surrebuttals. His victory was one of moral courage of a very high order, as well as one of thorough research and sharp polemical skills.

John was a serious man. But he was not solemn, except on solemn occasions. What I remembered best of Leo Strauss, in all the time we spent together alone, is that he lived to laugh. Strauss, however, was a giggler, whereas John-like Abraham Lincoln-was a roarer, or belly laugher. Let us remember him then in all his vitality, always seeking and finding the humorous side of things, the side that alone makes life bearable for those who are truly serious. When John arrived in San Jose to take up his professorial duties there, he sent a postcard to Claremont, addressed to me and to Martin Diamond. It read: "Dere profesors. Last munth I cuddent spel politikul sientist and now I are wun. John." Of course, to enjoy the full flavor of this, one would have to know something of the genuine and not so comical illiteracy of the profession, of which John was not so much gadfly as scourge. He could however laugh at others because he could laugh at himself. This he could do because he knew that in the end the comic reveals the truth more profoundly than the tragic. In this time of such great sadness, let us rejoice in the light and laughter and undimmed vitality of his too brief moment on this earth. 